
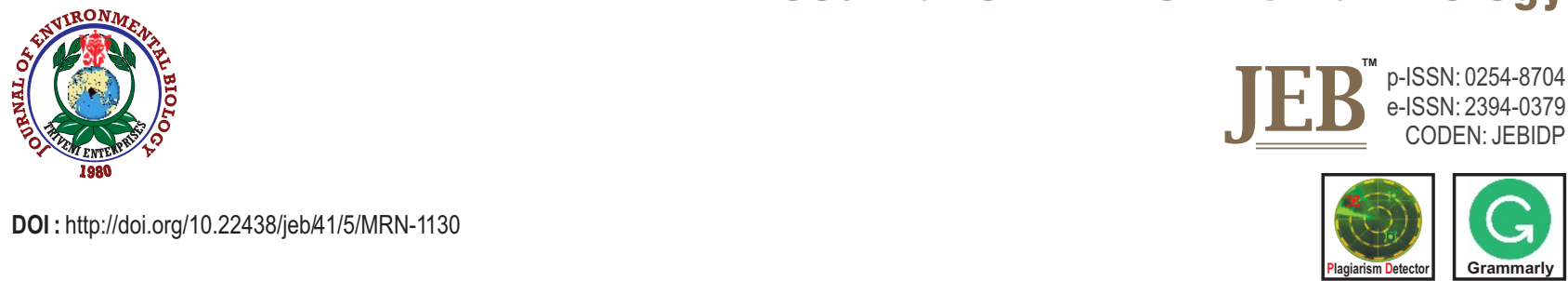

\title{
Vertical distribution of cationic micronutrients across landscape positions on Meghalayan plateau in the North-Eastern Region of India
}

\author{
P. Debroy ${ }^{1,2 *}$, R.K. Jena, P. Ray', S. Bandyopadhyay ${ }^{3}$, S. Padua ${ }^{4}$, S.K. Singh ${ }^{5}$ and S.K. Ray ${ }^{1}$ \\ ${ }^{1}$ ICAR-National Bureau of Soil Survey and Land Use Planning, Regional Centre, Jorhat-785 004, India \\ ${ }^{2}$ ICAR-Indian Institute of Water Management, Bhubaneswar-751 023, India \\ ${ }^{3}$ ICAR-National Bureau of Soil Survey and Land Use Planning, Regional Centre, Kolkata-700 091, India \\ ${ }^{4}$ ICAR-Central Marine Fisheries Research Institute, Kochi- 682 018, India \\ ${ }^{5}$ ICAR-National Bureau of Soil Survey and Land Use Planning, Nagpur-440 033, India \\ *Corresponding Author Email : partha.slg09@gmail.com
}

\section{Abstract}

Aim: The study aims to get insight about the depth wise distribution of fractions of cationic micronutrients ( $\mathrm{Fe}, \mathrm{Mn}, \mathrm{Zn}$ and $\mathrm{Cu}$ ) and their availability across various landscape positions in an elevational gradient of Meghalaya.

Methodology: Soils were collected from four different soil depth viz. 0-15, 15-30, 30-45 and 45-60 cm representing major landscape positions, i.e., plateau top, side slope, foot slope and valley in a catenary sequence in the Umsning block of Ri-bhoi district, Meghalaya.

Results: Cationic micronutrients and their fractions varied with soil depth and landscape positions in the study area. DTPA extractable Fe, Mn, Zn and Cu content was higher in surface layer as compared to the sub surface and found in higher amount in valley as compared to the other landscape positions. Zinc is the most limiting cationic micronutrient found in the study area, whereas poor availability of Mn was also observed in few sub-surface samples. Residual fraction was the largest fraction of cationic micronutrients in soil and varied from 58.4 to $71.0,33.8$ to $64.9,66.0$ to 84.1 and 30.1 to $65.6 \%$ of total $\mathrm{Fe}, \mathrm{Mn}, \mathrm{Zn}$ and $\mathrm{Cu}$, respectively in the study area. Soluble and exchangeable fraction is the most labile pool of cationic micronutrients in the study area though its content was less. Organically complexed fraction contributed in large to the availability of $\mathrm{Fe}, \mathrm{Zn}$ and $\mathrm{Cu}$. Whereas, amorphous and crystalline $\mathrm{Fe}$ oxide occluded fractions of $\mathrm{Zn}$ and $\mathrm{Cu}$ and crystalline oxide occluded fractions of $\mathrm{Mn}$ were also found to contribute the availability of respective cationic micronutrients as an indirect source.

Interpretation: Landscape position influences the distribution and availability of cationic micronutrients and their fractions in undulating terrain of Meghalaya through the distribution of clay, organic carbon and water content in soil profile. Moreover, present land use further modifies the availability of cationic micronutrients in the study area.

Key words: Catenary sequence, Depth-wise distribution, Meghalaya, Micronutrient fraction.
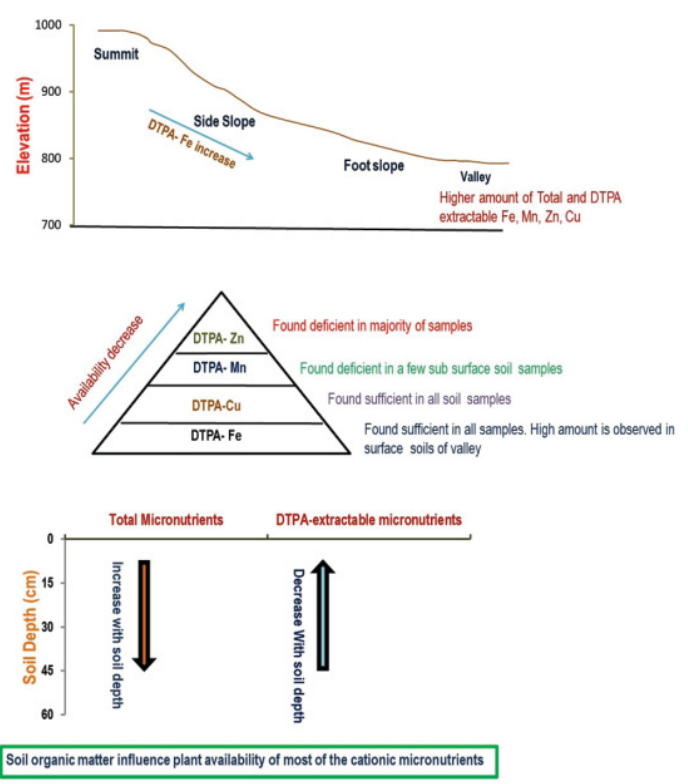

How to cite : Debroy, P., R.K. Jena, P. Ray, S. Bandyopadhyay, S. Padua, S.K. Singh and S.K. Ray: Vertical distribution of cationic micronutrients across landscape positions on Meghalayan plateau in the North Eastern Region of India. J. Environ. Biol., 41, 1089-1098 (2020). 


\section{Introduction}

Micronutrients are needed in a small quantity by plants relative to the macronutrients though the extents of micronutrientdeficient soils all over the world are increasing rapidly (Mortvedt, 2000). Alloway (2008) reported cationic micronutrient viz. $\mathrm{Zn}, \mathrm{Cu}$, $\mathrm{Mn}$ and $\mathrm{Fe}$ deficient area to the tune of $49,14,10$ and $3 \%$ respectively, over important agricultural soils of the world and the deficiency is severe in intensively cultivated land of highly weathered humid tropics (Graham, 2008). Analysis of surface soil across India reveals that on an average 36.5, 12.8, 7.1 and $4.2 \%$ soils were found deficient to $\mathrm{Zn}, \mathrm{Fe}, \mathrm{Mn}$ and $\mathrm{Cu}$ respectively (Shukla et al., 2018). Whereas, in the eastern part of India, nearly $29.8 \%$ of the total sample was deficient to $\mathrm{Zn}$ and $2.1 \%$ of $\mathrm{Cu}$, along with, multi micronutrient deficiency was also observed in significant numbers of samples (Shukla etal., 2014).

Total concentration of micronutrient in soil largely depends upon the bedrock from which parent material was formed and pedogenic weathering processes that leads to soil development from the parent material. With the advancement of soil profile development, the influence of parent material on soil micronutrient distribution decreases and the influence of microenvironment and soil properties viz., pH, redox potential become more prominent (Wei et al., 2006). Landscape position controls water movement within soil and thus eluviation and illuviation processes, which affect nutrient distribution in soils and its availability to plants and such effect is more prominent in hilly topography than level soil (Fisher and Binkley, 2000).

Cationic micronutrients viz. $\mathrm{Fe}, \mathrm{Mn}, \mathrm{Zn}$ and $\mathrm{Cu}$ in the soil remain in various pools as in solution, on exchange sites, chelated or complexed with organic matter, occluded on oxide or hydroxide or constituents of primary minerals. Distribution of cationic micronutrients in those fractions predicts the capacity of soil to long-term supply of nutrients in plant-available form and to retain toxic quantities (Adriano, 2001).

Meghalayan plateau, situated in the Northeastern Region (NER) of India, is one of the 12-biodiversity hot spots in the world. Though the region is rich in phytomass; deforestation, reduction in jhum cycle, massive soil erosion, soil acidity and multiple nutrient deficiencies pose serious threat to this ecosystem (Choudhury et al., 2013; Bandyopadhyay et al., 2018). The state is producing food grain far below to their potentials and deficit by 3.4 lakh tones annually (Singh and Ngachan, 2012). Micronutrient availability is considered an important factor that governs quantity as well as the quality of the food grain produce (Kumar et al., 2016; Deb Roy et al. 2014). Intensive cultivation practices without replenishment of micronutrients in the soil through manure or fertilizer is anticipated to aggravate the situation further (Takkar and Shukla, 2015). At present, there is very little information available regarding spatial and vertical variability of cationic micronutrients in highly leached soils of
Meghalaya. Therefore, an attempt was made to study depth-wise distribution of cationic micronutrients across major landscape positions and their distribution in several fractions which is a prerequisite for better management of soils over such undulating terrain in NER of India.

\section{Materials and Methods}

Site description: The study area covers Umsning block of Ribhoi district, Meghalaya, which is located in the south eastern part of Ri-bhoi district. Soils in the study area are developed mainly from granite-gneissic parent material. Climate in the state is per humid in nature with a mean annual rainfall (MAR) of $2395 \mathrm{~mm}$. The mean summer and winter temperature comprises $24^{\circ} \mathrm{C}$ and $12^{\circ} \mathrm{C}$ respectively in the study area.

Site selection, sampling procedure and laboratory analysis methods: A reconnaissance survey was performed by traversing the area and four landscape positions, i.e., plateau top, side slope, foot slope and valley in a catenary sequence were identified for sampling. At each landscape positions, three profiles were sampled as replicates and soils were collected from four different soil depth viz., 0-15, 15-30, 30-45 and 45-60 cm from each soil profile. Soils in the top of the plateau under natural vegetation were highly weathered with hue ranging from $5 \mathrm{YR}$ to 2.5 YR. At the side slope position, slope percentage was 10-20\% and the top soils were almost eroded. Scrub forest was the dominant land cover in this landscape position. At the foot slope (3-5\% slope), soils were deep and the landscape position was under horticultural crops. In valley (1-3\% slope) soils were very deep. High water table throughout the year made it suitable mainly for paddy cultivation. Soils were classified as ultisols in elevated landscapes, whereas in valley, soil comes under inceptisols soil order. Soil samples were air dried, grounded and passed through $2 \mathrm{~mm}$ sieve for laboratory analysis. Analysis of particle size was done as per International pipette method (Piper, 1966). Soil $\mathrm{pH}\left(\mathrm{pH}_{\mathrm{w}}\right)$ was determined in soil-water $(1: 2.5)$ suspension (Jackson, 1958). Organic carbon was determined by the wet oxidation method (Walkley and Black, 1934) and CEC by the ammonium acetate method (Hesse, 1971). Total micronutrient contents in the soil samples were determined by digesting $0.1 \mathrm{~g}$ samples in tri acid mixture of $\mathrm{HF}-\mathrm{H}_{2} \mathrm{SO}_{4}-\mathrm{HClO}_{4}$ (Lim and Jackson, 1982). DTPA extractable fractions of micronutrients were extracted from the soil with DTPA, $\mathrm{CaCl}_{2}$ and triethanolamine, as described by Lindsay and Norvell (1978). Various fractions of micronutrients viz., water soluble plus exchangeable, organically complexed, $\mathrm{Mn}$ oxide bound, amorphous and crystalline oxide occluded fraction were determined with sequential extraction of soil samples following the method described by Mandal and Mandal (1986). Water soluble and exchangeable fraction was determined through extraction of soil with $1 \mathrm{~N} \mathrm{NH}_{4} \mathrm{OAc}(\mathrm{pH} 7)$ after shaking the soil for $30 \mathrm{~min}$ (Step 1). Organically complexed fraction was determined by overnight shaking of the residue of step 1 with $0.1 \mathrm{M} \mathrm{K}_{4} \mathrm{P}_{2} \mathrm{O}_{7}$ 
(Step 2) To the residue soil of step 2, $0.1 \mathrm{M} \mathrm{NH}_{2} \mathrm{OH} . \mathrm{HCl}(\mathrm{pH} 2)$ was added and the mixture was shaken for $30 \mathrm{~min}$ to determine $\mathrm{Mn}$ oxides bound fraction (Step 3). The residue from step 3 was shaken for $4 \mathrm{hrs}$. after addition of $0.2 \mathrm{M}\left(\mathrm{NH}_{4}\right)_{2} \mathrm{C}_{2} \mathrm{O}_{4}$ and $0.2 \mathrm{M}$ $\mathrm{H}_{2} \mathrm{C}_{2} \mathrm{O}_{4}(\mathrm{pH} 3)$ to determine amorphous Fe-oxides occluded fraction of micronutrients (Step 4). The residue soil of step 4 was mixed with $0.2 \mathrm{M}\left(\mathrm{NH}_{4}\right)_{2} \mathrm{C}_{2} \mathrm{O}_{4}, 0.2 \mathrm{M} \mathrm{H}_{2} \mathrm{C}_{2} \mathrm{O}_{4}$ and $0.1 \mathrm{M}$ ascorbic acid, at $\mathrm{pH} 3$. The mixture was boiled in water bath for $30 \mathrm{~min}$ and stirred occasionally. The solution was filtered and analyzed for crystalline Fe-oxides occluded fraction of micronutrients (Step 5). Soil $(\mathrm{g})$ to solution $(\mathrm{ml})$ ratio was fixed to 5 : 50 for each step of sequential extraction procedure. The residual fraction was determined by deducting the sum of all the fractions from the total amount of micronutrient. Micronutrients in the soil extracts were measured by an atomic absorption spectrophotometer (Make: Shimadzu).

Statistical analysis: Descriptive statistics, Pearson correlation coefficient was performed in EXCEL $® 2007$ software. The data of micronutrient content were subjected to statistical analysis of variance (ANOVA) using randomized block design. ANOVA as well as factor analysis was performed using SAS 9.3 software.

\section{Results and Discussion}

Soil reaction was strong to moderately acidic (4.9 to 6.2) up to $60 \mathrm{~cm}$ of soil depth in the study area. Soil $\mathrm{pH}_{\mathrm{w}}$ increased significantly with depth irrespective of landscape position and land use (Table 1). Acidic surface soils are mainly due to high rainfall and leaching of bases under per-humid climatic condition.
Organic carbon $(\mathrm{OC})$ content varied from 1.3 to $2.6 \%$ in the surface $(0-15 \mathrm{~cm})$ soils (Table 1$)$. Majority $(75 \%)$ of the surface soil under high organic carbon category $(>1.5 \%)$ might be due to the higher accumulation of biomass and low mean annual temperature prevailing in the study area (Nayak et al., 1996). The clay percentage increased with soil depth and accumulated in the $B$ horizon, particularly on plateau top and side slope position (Table 1). Translocation of clay from the surface and its accumulation in B horizon in an elevated landscape of Meghalaya was also reported by Bhattacharya et al. (1994).

Total contents of $\mathrm{Fe}, \mathrm{Mn}, \mathrm{Zn}$ and $\mathrm{Cu}$ in the soil up to $60 \mathrm{~cm}$ soil depth, varied from 2.1 to $4.1 \%, 125.7$ to $884.9 \mathrm{ppm}, 31.1$ to $155.1 \mathrm{ppm}$ and 12.5 to $71.7 \mathrm{ppm}$ with a mean value of $3.1 \%, 404.6$ ppm, 65.5 ppm and 27.5 ppm, respectively (Fig. 1). The total content of $\mathrm{Fe}, \mathrm{Mn}, \mathrm{Zn}$ and $\mathrm{Cu}$ was found in higher amount in subsurface soil, particularly at $15-45 \mathrm{~cm}$ soil depth as compared to the surface $(0-15 \mathrm{~cm})$ in all the landscape position except in valley. Release of cationic micronutrient from surface and their deposition to sub surface layer in highly weathered soil profile due to pedogenic processes was reported by Sharma et al. (2005). In the valley, total $\mathrm{Mn}, \mathrm{Zn}$ and Cu were comparatively higher than other landscape positions. Restricted drainage condition, along with periodic deposition of top soil from elevated landscape might be responsible for such higher values.

DTPA-Fe ranged from 34.8 to $94.1 \mathrm{ppm}$ in surface soil of the study area and was found to be sufficient ( $>4.5 \mathrm{ppm}$ ) in all the soil samples (Table 2). DTPA extracted $\mathrm{Mn}, \mathrm{Zn}$ and $\mathrm{Cu}$ concentrations in surface soils varied from 4.0 to $13.8,0.27$ to

Table 1: Selected soil physico-chemical properties under different landscape positions in Meghalayan plateau, North-eastern India

\begin{tabular}{|c|c|c|c|c|c|c|c|}
\hline $\begin{array}{l}\text { Landscape } \\
\text { position }\end{array}$ & $\begin{array}{l}\text { Soil depth } \\
(\mathrm{cm})\end{array}$ & $\mathrm{pH}_{\mathrm{w}}(1: 2.5)$ & Org.C. (\%) & $\begin{array}{l}\text { CEC } \\
{\left[\mathrm{cmol}\left(\mathrm{p}^{+}\right) \mathrm{kg}^{-1}\right]}\end{array}$ & $\begin{array}{l}\text { Sand } \\
(\%)\end{array}$ & $\begin{array}{l}\text { Silt } \\
(\%)\end{array}$ & $\begin{array}{l}\text { Clay } \\
(\%)\end{array}$ \\
\hline \multirow[t]{5}{*}{ Plateau Top } & $0-15$ & $5.3 \pm 0.1$ & $2.1 \pm 0.1$ & $8.2 \pm 0.5$ & $14.8 \pm 1.5$ & $31.6 \pm 2.2$ & $53.6 \pm 3.0$ \\
\hline & $15-30$ & $5.6 \pm 0.2$ & $1.2 \pm 0.1$ & $7.0 \pm 0.4$ & $14.1 \pm 1.4$ & $23.0 \pm 2.1$ & $62.9 \pm 4.0$ \\
\hline & $30-45$ & $5.7 \pm 0.1$ & $0.6 \pm 0.1$ & $5.0 \pm 0.5$ & $14.1 \pm 1.1$ & $20.1 \pm 1.7$ & $65.8 \pm 3.7$ \\
\hline & $45-60$ & $5.7 \pm 0.1$ & $0.4 \pm 0.0$ & $5.1 \pm 0.3$ & $12.9 \pm 1.7$ & $22.8 \pm 1.4$ & $64.4 \pm 3.9$ \\
\hline & Mean & 5.6 & 1.1 & 6.3 & 14.0 & 24.4 & 61.7 \\
\hline \multirow[t]{5}{*}{ Side slope } & $0-15$ & $5.5 \pm 0.1$ & $1.8 \pm 0.1$ & $10.4 \pm 0.5$ & $27.2 \pm 2.3$ & $25.8 \pm 1.9$ & $46.9 \pm 3.4$ \\
\hline & $15-30$ & $5.4 \pm 0.1$ & $1.3 \pm 0.1$ & $8.9 \pm 0.5$ & $23.5 \pm 2.6$ & $25.8 \pm 2.2$ & $50.7 \pm 3.9$ \\
\hline & $30-45$ & $5.5 \pm 0.2$ & $1.0 \pm 0.1$ & $8.2 \pm 0.4$ & $22.8 \pm 1.7$ & $23.3 \pm 1.7$ & $53.9 \pm 2.7$ \\
\hline & $45-60$ & $5.7 \pm 0.3$ & $0.9 \pm 0.1$ & $8.4 \pm 0.4$ & $23.0 \pm 1.7$ & $25.6 \pm 1.4$ & $51.4 \pm 2.4$ \\
\hline & Mean & 5.5 & 1.3 & 9.0 & 24.1 & 25.1 & 50.7 \\
\hline \multirow[t]{5}{*}{ Foot slope } & $0-15$ & $4.9 \pm 0.2$ & $2.6 \pm 0.1$ & $12.4 \pm 0.7$ & $17.5 \pm 1.8$ & $41.7 \pm 0.8$ & $40.7 \pm 3.7$ \\
\hline & $15-30$ & $4.9 \pm 0.2$ & $2.3 \pm 0.2$ & $12.9 \pm 0.8$ & $17.8 \pm 1.7$ & $43.2 \pm 2.4$ & $39.0 \pm 3.4$ \\
\hline & $30-45$ & $5.1 \pm 0.1$ & $1.4 \pm 0.2$ & $11.4 \pm 0.6$ & $18.4 \pm 2.0$ & $41.6 \pm 2.3$ & $40.0 \pm 3.2$ \\
\hline & $45-60$ & $5.1 \pm 0.1$ & $0.7 \pm 0.1$ & $10.3 \pm 0.5$ & $18.8 \pm 1.7$ & $40.9 \pm 2.3$ & $40.3 \pm 2.7$ \\
\hline & Mean & 5.0 & 1.7 & 11.8 & 18.1 & 41.9 & 40.0 \\
\hline \multirow[t]{5}{*}{ Valley } & $0-15$ & $5.6 \pm 0.1$ & $1.30 \pm 0.1$ & $11.3 \pm 0.7$ & $12.7 \pm 1.0$ & $59.7 \pm 1.9$ & $27.6 \pm 2.1$ \\
\hline & $15-30$ & $5.9 \pm 0.2$ & $0.9 \pm 0.1$ & $9.6 \pm 0.7$ & $42.2 \pm 2.5$ & $36.7 \pm 1.2$ & $21.1 \pm 1.8$ \\
\hline & $30-45$ & $5.9 \pm 0.1$ & $1.5 \pm 0.1$ & $9.8 \pm 0.6$ & $19.2 \pm 2.2$ & $53.2 \pm 2.9$ & $27.6 \pm 2.8$ \\
\hline & $45-60$ & $6.2 \pm 0.1$ & $0.5 \pm 0.0$ & $6.8 \pm 0.5$ & $53.9 \pm 2.0$ & $27.9 \pm 1.5$ & $18.2 \pm 1.6$ \\
\hline & Mean & 5.9 & 1.1 & 9.4 & 32.0 & 44.4 & 23.6 \\
\hline
\end{tabular}


(A)

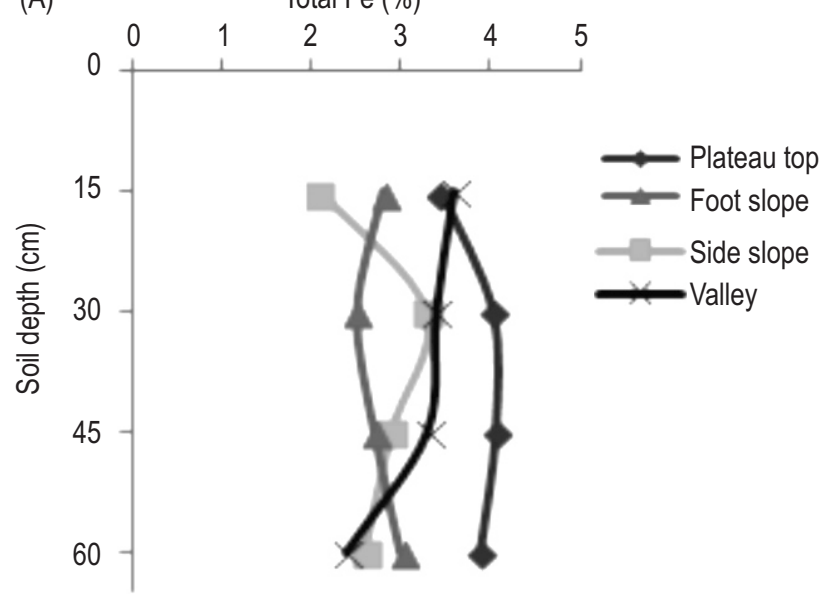

(C)

$\begin{array}{llllll}10 & 40 & 70 & 100 & 130 & 160\end{array}$

(B)

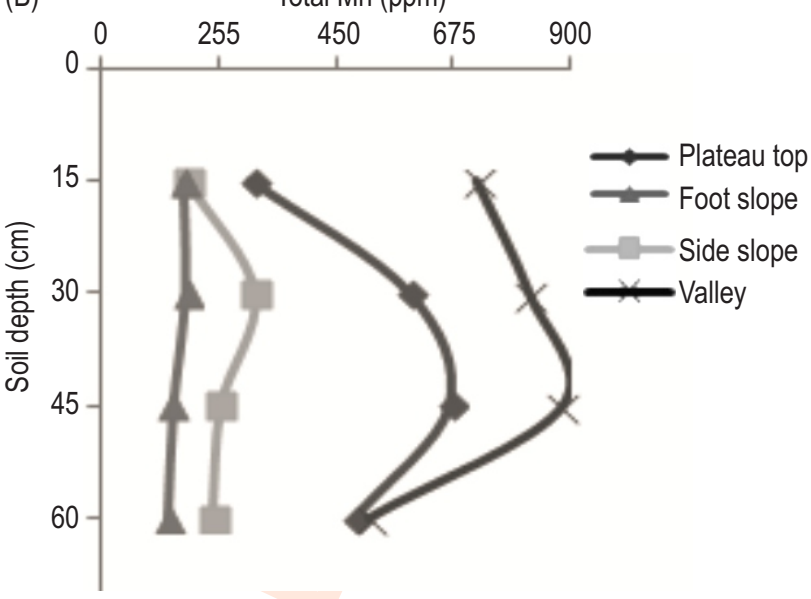

(D)

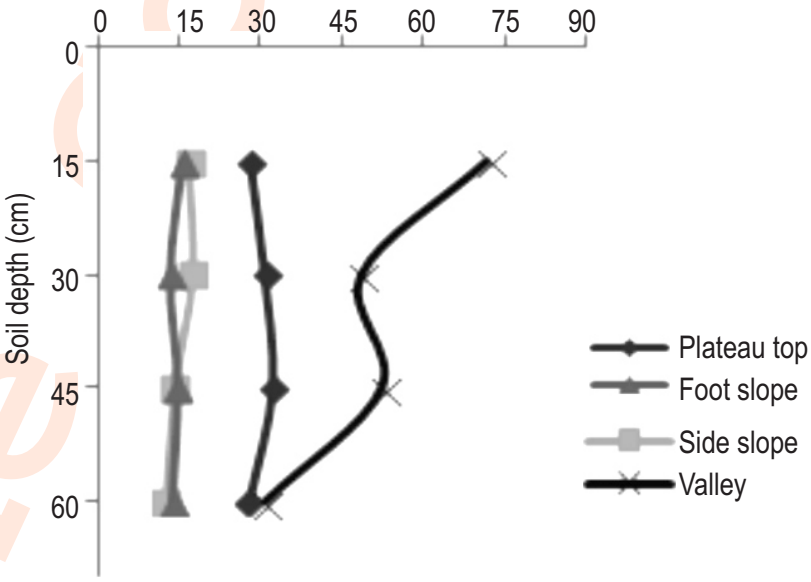

Fig. 1 : Depth wise distribution of $(A)$ total Fe; $(B)$ total $\mathrm{Mn} ;(C)$ total $\mathrm{Zn}$ and $(\mathrm{D})$ total Cu under different landscape positions in Meghalayan plateau, NorthEastern India.

0.78 and 0.74 to 6.44 ppm, respectively. DTPA-Mn was found above the critical limit of 3.5 ppm (Nayyar et al., 1985) in surface soil $(0-15 \mathrm{~cm})$ of all the landscape positions, whereas its deficiency was observed in the sub-surface soil, particularly at foot slope position. In case of zinc, it was measured below the critical limit of $0.6 \mathrm{ppm}$ (Takkar and Mann, 1975) in the surface soil of side slope and foot slope positions, whereas in valley and plateau top it was marginally higher than the critical limit. All the soils are found to be sufficient considering $0.2 \mathrm{ppm}$ as critical level of copper (Lindsay and Norvell, 1978). In the surface layer, DTPA extractable $\mathrm{Fe}, \mathrm{Zn}$ and $\mathrm{Cu}$ contents were found to be in higher amount and it decreased along with depth in all landscape positions might be due to biogeochemical cycling and their deposition in the surface through plant litter or dead roots (Lee et al., 1997). The clay content of the soil was negatively correlated with extractable $\mathrm{Fe}$ and $\mathrm{Cu}\left(\mathrm{Fe}_{\mathrm{r}}=-0.69^{* *}, \mathrm{Cu}_{\mathrm{r}}=-0.70^{* *}\right)$ and poorly correlated with DTPA-Zn and Mn content. Thus, clay content was a poor indicator of extractable $\mathrm{Zn}\left(R^{2}=3 \%\right)$ and $\mathrm{Mn}\left(R^{2}=6 \%\right)$ variability in such a highly weathered soil. Soil organic carbon was positively correlated with DTPA-Fe $\left(r=0.35^{*}\right)$ and $\mathrm{Zn}\left(\mathrm{r}=0.60^{* *}\right)$. Similar to Fe and Zn, DTPA-Cu also positively correlated with soil organic carbon $\left(r=0.80^{* *}\right)$ in all the landscapes, excluding valley.

Among all the fractions of micronutrients in soil, 'watersoluble and exchangeable fraction' (WS+EX) is considered as the most readily available fraction to the plants. This fraction of $\mathrm{Fe}$ varied from 0.38 to $3.39 \mathrm{ppm}$ in the surface soil and it decreased along with soil depth in all the pedons (Table 3). WS+EX-Mn varied from 3.3 to $11.6 \mathrm{ppm}$ in surface soils (Table 4). This fraction of Mn was found higher in surface as compared to sub-surface. Depth wise distribution of this fraction of Mn did not follow clay distribution pattern as evident from poor correlation with clay content ( $r=0.15)$, similar to the findings of Agbenin (2003). The higher amount of WS+EX-Fe (1.17 ppm) and Mn (11.6 ppm) was observed in the surface of the valley as compared to the other landscapes, might be due to prevailing reducing condition in 
Table 2: DTPA extractable fractions of $\mathrm{Fe}, \mathrm{Mn}, \mathrm{Zn}$ and Cu under different landscape positions in Meghalayan plateau, North-Eastern India

\begin{tabular}{|c|c|c|c|c|c|}
\hline Landscape position & Soil depth (cm) & DTPA-Fe (mg kg $\left.{ }^{-1}\right)$ & DTPA-Mn (mg kg $\left.{ }^{-1}\right)$ & DTPA-Zn (mg kg $\left.{ }^{-1}\right)$ & DTPA-Cu (mg kg $\left.{ }^{-1}\right)$ \\
\hline \multirow[t]{6}{*}{ Plateau Top } & $0-15$ & $41.1 \pm 1.8$ & $6.6 \pm 0.3$ & $0.77 \pm 0.06$ & $1.96 \pm 0.13$ \\
\hline & $15-30$ & $13.8 \pm 1.6$ & $6.1 \pm 0.2$ & $0.12 \pm 0.02$ & $0.43 \pm 0.02$ \\
\hline & $30-45$ & $7.0 \pm 1.2$ & $7.4 \pm 0.1$ & $0.02 \pm 0.00$ & $0.24 \pm 0.03$ \\
\hline & $45-60$ & $8.4 \pm 0.8$ & $5.7 \pm 0.1$ & $0.01 \pm 0.00$ & $0.23 \pm 0.03$ \\
\hline & Mean & 17.6 & 6.4 & 0.23 & 0.71 \\
\hline & $\mathrm{CD}_{0.05}$ & 1.5 & 0.3 & 0.10 & 0.22 \\
\hline \multirow[t]{6}{*}{ Side slope } & $0-15$ & $34.8 \pm 2.5$ & $4.0 \pm 0.2$ & $0.27 \pm 0.03$ & $0.74 \pm 0.03$ \\
\hline & $15-30$ & $18.7 \pm 1.9$ & $3.2 \pm 0.2$ & $0.01 \pm 0.00$ & $0.42 \pm 0.03$ \\
\hline & $30-45$ & $15.7 \pm 1.7$ & $3.7 \pm 0.2$ & $0.02 \pm 0.00$ & $0.38 \pm 0.02$ \\
\hline & $45-60$ & $12.5 \pm 1.8$ & $3.9 \pm 0.3$ & $0.01 \pm 0.00$ & $0.42 \pm 0.02$ \\
\hline & Mean & 20.4 & 3.7 & 0.08 & 0.49 \\
\hline & $\mathrm{CD}_{0.05}$ & 1.5 & 0.3 & 0.05 & 0.04 \\
\hline \multirow[t]{6}{*}{ Footslope } & $0-15$ & $38.3 \pm 2.2$ & $5.2 \pm 0.2$ & $0.52 \pm 0.02$ & $0.97 \pm 0.03$ \\
\hline & $15-30$ & $37.3 \pm 1.7$ & $2.9 \pm 0.2$ & $0.20 \pm 0.05$ & $0.84 \pm 0.03$ \\
\hline & $30-45$ & $39.5 \pm 1.9$ & $1.4 \pm 0.2$ & $0.10 \pm 0.05$ & $0.81 \pm 0.04$ \\
\hline & $45-60$ & $36.9 \pm 1.9$ & $0.9 \pm 0.2$ & $0.07 \pm 0.01$ & $0.77 \pm 0.04$ \\
\hline & Mean & 38.0 & 2.6 & 0.22 & 0.85 \\
\hline & $\mathrm{CD}_{0.05}$ & 1.0 & 0.2 & 0.08 & 0.06 \\
\hline \multirow[t]{6}{*}{ Valley } & $0-15$ & $94.1 \pm 2.1$ & $13.8 \pm 0.6$ & $0.78 \pm 0.10$ & $6.44 \pm 0.3$ \\
\hline & $15-30$ & $40.7 \pm 2.0$ & $3.6 \pm 0.3$ & $0.07 \pm 0.01$ & $3.07 \pm 0.3$ \\
\hline & $30-45$ & $54.4 \pm 1.7$ & $6.1 \pm 0.2$ & $0.14 \pm 0.01$ & $4.43 \pm 0.3$ \\
\hline & $45-60$ & $33.1 \pm 1.7$ & $2.5 \pm 0.2$ & $0.08 \pm 0.01$ & $2.13 \pm 0.3$ \\
\hline & Mean & 55.6 & 6.5 & 0.27 & 4.02 \\
\hline & $\mathrm{CD}_{0.05}$ & 3.7 & 0.7 & 0.09 & 0.53 \\
\hline
\end{tabular}

valley. WS+EX-Zn ranged from 0.16 to $0.89 \mathrm{ppm}$ in the surface soil of the study area and were found significantly higher in the surface as compared to sub-surface (Table 5). WS+EX-Cu contributed 0.8 to $4.7 \%$ of total $\mathrm{Cu}$ in all the soils which was in contrast to the findings of Nascimento et al. (2006) (Table 6). They reported an undetectable amount of exchangeable $\mathrm{Cu}$ in different soils of Brazil. Overall, soluble and exchangeable micronutrients were found higher in the surface as compared to sub-surface which might be due to variation in soil organic carbon content and biogeochemical cycling (Rengel, 2015).

Organically complexed (ORG) Fe fraction was found in the range 3302.2 to $5874.3 \mathrm{ppm}$ in the surface soil of the study area (Table 3). Among different landscape position, ORG-Fe followed the decreasing order as foot slope (4732.4 ppm) > side slope (3169.2 ppm) > valley (3092.9 ppm) > plateau top (2898.9 $\mathrm{ppm}$ ) in the study area. Distribution of organic carbon in various landscape position ultimately control the variability as depicted from significant correlation with organic bound iron $\left(r=0.76^{* *}\right)$. ORG-Mn varied from 26.0 to $97.8 \mathrm{ppm}$ in surface soil of the study area (Table 4). This fraction of Fe and $\mathrm{Mn}$ was found in higher amount at 0-30 cm soil layer in most of the pedon except in valley, where higher amount was found at $30-45 \mathrm{~cm}$ soil layer. Poor stability of ORG-Fe and ORG-Mn in reduced condition of valley and subsequent movement to deeper layer might be the probable reason (Adhikari and Yang, 2015). Similar to Fe and Mn, ORG-Zn and ORG-Cu contents were comparatively higher in surface soil than the sub-surface layer. On an average, ORG-Zn fraction contributed $4.4 \%$ of total Zn whereas, ORG-Cu contributed $17.0 \%$ of total $\mathrm{Cu}$ in the study area (Table 5 and 6 ).

Mn oxide bound (MnOX) Fe fraction varied from 104.7 to $1255.6 \mathrm{ppm}$ in the surface soil of the study area (Table 3). Higher amount of MnOX-Fe content at 0-15 and $45-60 \mathrm{~cm}$ depth is due to eluviation and illuviation processes. Irregular distribution of MnOX-Fe content, particularly in side slope was due to its unstable landscape position. This fraction of Mn was found in the range 2.9 to $30.3 \mathrm{ppm}$ in surface soils and was increased along with depth in all the landscape positions (Table 4) due to higher mobility of released $\mathrm{Mn}$ from surface as compared to Fe and its subsequent deposition to deeper layer (Mcdaniel et al., 1992). It was more concentrated in the valley (67.8 ppm) as compared to other landscapes. Little amount of total $\mathrm{Zn}(0.1$ to $1.4 \%)$ and $\mathrm{Cu}$ (up to $1.3 \%$ ) (Table 5 and 6 ) was bound by secondary Mn oxides. Similar to $\mathrm{Fe}$ and $\mathrm{Mn}$, comparatively higher amount of $\mathrm{Zn}$ was bound with Mn oxide in the valley ( $0.50 \mathrm{ppm})$. The oscillating water table in valley leads to accumulation of plenty of secondary $\mathrm{Mn}$ oxide nodules which bound micronutrient cations (Post, 1999).

Amorphous Fe-oxides occluded (AFeOX) Fe fraction varied from 2756.5 to $4059.0 \mathrm{ppm}$ in the surface soil of the study area (Table 3). In plateau top, side slope and foot slope position, the higher amount of amorphous iron were observed at 30-45 cm depth. Co-migration of AFeOX- Fe along with clay might be the 
Table 3 : Iron fractions under different landscape positions in Meghalayan plateau, North-Eastern India

\begin{tabular}{|c|c|c|c|c|c|c|c|}
\hline $\begin{array}{l}\text { Landscape } \\
\text { position }\end{array}$ & $\begin{array}{l}\text { Soil depth } \\
\text { (cm) }\end{array}$ & $\begin{array}{l}\text { WS+EX-Fe } \\
\left(\mathrm{mg} \mathrm{kg}^{-1}\right)\end{array}$ & $\begin{array}{l}\text { ORG-Fe } \\
\left(\mathrm{mg} \mathrm{kg}^{-1}\right)\end{array}$ & $\begin{array}{l}\text { MnOX-Fe } \\
\left(\mathrm{mg} \mathrm{kg}^{-1}\right)\end{array}$ & $\begin{array}{l}\text { AFeOX-Fe } \\
\left(\mathrm{mg} \mathrm{kg}^{-1}\right)\end{array}$ & $\begin{array}{l}\text { CFeOX-Fe } \\
\left(\mathrm{mg} \mathrm{kg}^{-1}\right)\end{array}$ & $\begin{array}{l}\text { RES-Fe } \\
\left(\mathrm{mg} \mathrm{kg}^{-1}\right)\end{array}$ \\
\hline \multirow[t]{6}{*}{ Plateau Top } & $0-15$ & $\begin{array}{l}1.10 \pm .08 \\
(<.01)\end{array}$ & $\begin{array}{l}5874.3 \pm 318.1 \\
(17.0)\end{array}$ & $\begin{array}{l}104.7 \pm 4.8 \\
(0.3)\end{array}$ & $\begin{array}{l}4059.0 \pm 186.0 \\
(11.7)\end{array}$ & $\begin{array}{l}4258.2 \pm 195.1 \\
(12.3)\end{array}$ & $\begin{array}{l}20210.4 \pm 926.2 \\
(58.6)\end{array}$ \\
\hline & $15-30$ & $\begin{array}{l}0.11 \pm .02 \\
(<.01)\end{array}$ & $\begin{array}{l}4716.2 \pm 257.7 \\
(11.7)\end{array}$ & $\begin{array}{l}42.9 \pm 4.8 \\
(0.1)\end{array}$ & $\begin{array}{l}4104.8 \pm 79.3 \\
(10.1)\end{array}$ & $\begin{array}{l}4294.4 \pm 166.0 \\
(10.6)\end{array}$ & $\begin{array}{l}27211.1 \pm 1382.0 \\
(67.4)\end{array}$ \\
\hline & $30-45$ & $\begin{array}{l}0.05 \pm .01 \\
(<.01)\end{array}$ & $\begin{array}{l}590.7 \pm 101.5 \\
(1.4)\end{array}$ & $\begin{array}{l}39.3 \pm 1.8 \\
(0.1)\end{array}$ & $\begin{array}{l}4129.0 \pm 131.0 \\
(10.1)\end{array}$ & $\begin{array}{l}4373.2 \pm 166.6 \\
(10.7)\end{array}$ & $\begin{array}{l}31560.1 \pm 948.0 \\
(77.6)\end{array}$ \\
\hline & $45-60$ & $\begin{array}{l}0.06 \pm .01 \\
(<.01)\end{array}$ & $\begin{array}{l}414.4 \pm 29.2 \\
(1.1)\end{array}$ & $\begin{array}{l}355.9 \pm 35.1 \\
(0.9)\end{array}$ & $\begin{array}{l}3444.0 \pm 89.1 \\
(8.8)\end{array}$ & $\begin{array}{l}3607.7 \pm 233.1 \\
(9.2)\end{array}$ & $\begin{array}{l}31099.3 \pm 1242.0 \\
(79.9)\end{array}$ \\
\hline & Mean & $0.33(<.01)$ & $2898.9(7.7)$ & $135.7(0.3)$ & $3934.2(10.2)$ & $4133.4(10.7)$ & $27520.2(71.0)$ \\
\hline & $\mathrm{CD}_{0.05}$ & 0.16 & 527.3 & 55.8 & 270.4 & 486.9 & 2193.0 \\
\hline \multirow[t]{6}{*}{ Side slope } & $0-15$ & $\begin{array}{l}0.38 \pm .07 \\
(<.01)\end{array}$ & $\begin{array}{l}3302.2 \pm 221.4 \\
(15.4)\end{array}$ & $\begin{array}{l}322.8 \pm 14.6 \\
(1.5)\end{array}$ & $\begin{array}{l}2883.2 \pm 131.4 \\
(13.5)\end{array}$ & $\begin{array}{l}3101.6 \pm 171.4 \\
(14.5)\end{array}$ & $\begin{array}{l}11791.4 \pm 664.0 \\
(55.1)\end{array}$ \\
\hline & $15-30$ & $\begin{array}{l}0.16 \pm .02 \\
(<.01)\end{array}$ & $\begin{array}{l}3921.0 \pm 325.8 \\
(11.8)\end{array}$ & $\begin{array}{l}406.0 \pm 19.2 \\
(1.2)\end{array}$ & $\begin{array}{l}2895.4 \pm 144.0 \\
(8.7)\end{array}$ & $\begin{array}{l}2534.9 \pm 117.5 \\
(7.7)\end{array}$ & $\begin{array}{l}23311.2 \pm 1609.2 \\
(70.5)\end{array}$ \\
\hline & $30-45$ & $\begin{array}{l}0.22 \pm .02 \\
(<.01)\end{array}$ & $\begin{array}{l}2642.5 \pm 161.0 \\
(9.1)\end{array}$ & $\begin{array}{l}229.5 \pm 20.0 \\
(0.8)\end{array}$ & $\begin{array}{l}2940.0 \pm 132.4 \\
(10.1)\end{array}$ & $\begin{array}{l}3153.0 \pm 128.6 \\
(10.9)\end{array}$ & $\begin{array}{l}20038.3 \pm 1834.4 \\
(69.0)\end{array}$ \\
\hline & $45-60$ & $\begin{array}{l}0.19 \pm .04 \\
(<.01)\end{array}$ & $\begin{array}{l}2811.6 \pm 406.0 \\
(10.9)\end{array}$ & $\begin{array}{l}139.3 \pm 13.4 \\
(0.5)\end{array}$ & $\begin{array}{l}2904.4 \pm 136.5 \\
(11.3)\end{array}$ & $\begin{array}{l}3159.1 \pm 193.6 \\
(12.1)\end{array}$ & $\begin{array}{l}16796.5 \pm 1543.2 \\
(65.1)\end{array}$ \\
\hline & Mean & $0.24(<.01)$ & $3169.2(11.6)$ & $274.4(1.0)$ & $2905.7(10.6)$ & $2987.2(10.9)$ & $17984.4(65.8)$ \\
\hline & $\mathrm{CD}_{0.05}$ & 0.14 & 776.2 & 33.2 & NS & 325.6 & 2616.5 \\
\hline \multirow[t]{6}{*}{ Foot slope } & $0-15$ & $\begin{array}{l}0.84 \pm .07 \\
(<.01)\end{array}$ & $\begin{array}{l}4611.7 \pm 511.5 \\
(16.3)\end{array}$ & $\begin{array}{l}1255.6 \pm 99.9 \\
(4.5)\end{array}$ & $\begin{array}{l}2756.5 \pm 111.4 \\
(9.8)\end{array}$ & $\begin{array}{l}3131.0 \pm 286.1 \\
(11.1)\end{array}$ & $\begin{array}{l}16452.7 \pm 1294.8 \\
(58.3)\end{array}$ \\
\hline & $15-30$ & $\begin{array}{l}0.53 \pm .09 \\
(<.01)\end{array}$ & $\begin{array}{l}5203.2 \pm 308.6 \\
(20.5)\end{array}$ & $\begin{array}{l}725.8 \pm 47.8 \\
(2.9)\end{array}$ & $\begin{array}{l}2705.1 \pm 176.2 \\
(10.6)\end{array}$ & $\begin{array}{l}3103.3 \pm 255.6 \\
(12.2)\end{array}$ & $\begin{array}{l}13650.0 \pm 1289.9 \\
(53.8)\end{array}$ \\
\hline & $30-45$ & $\begin{array}{l}0.64 \pm .04 \\
(<.01)\end{array}$ & $\begin{array}{l}4977.2 \pm 655.3 \\
(18.2)\end{array}$ & $\begin{array}{l}969.6 \pm 56.8 \\
(3.6)\end{array}$ & $\begin{array}{l}2897.6 \pm 117.4 \\
(10.6)\end{array}$ & $\begin{array}{l}2923.8 \pm 250.2 \\
(10.7)\end{array}$ & $\begin{array}{l}15528.5 \pm 1707.9 \\
(56.9)\end{array}$ \\
\hline & $45-60$ & $\begin{array}{l}0.50 \pm .11 \\
(<.01)\end{array}$ & $\begin{array}{l}4137.6 \pm 367.8 \\
(13.5)\end{array}$ & $\begin{array}{l}1156.7 \pm 97.0 \\
(3.8)\end{array}$ & $\begin{array}{l}2838.9 \pm 110.9 \\
(9.3)\end{array}$ & $\begin{array}{l}2979.6 \pm 164.8 \\
(9.7)\end{array}$ & $\begin{array}{l}19499.7 \pm 1445.8 \\
(63.7)\end{array}$ \\
\hline & Mean & $0.63(<.01)$ & $4732.4(17.0)$ & $1026.9(3.7)$ & $2799.5(10.0)$ & $3034.4(10.9)$ & $16282.7(58.4)$ \\
\hline & $\mathrm{CD}_{0.05}$ & 0.17 & 646.3 & 110.4 & 117.8 & NS & 2146.7 \\
\hline \multirow[t]{6}{*}{ Valley } & $0-15$ & $\begin{array}{l}3.39 \pm 0.22 \\
(<.01)\end{array}$ & $\begin{array}{l}3569.2 \pm 160.7 \\
(9.8)\end{array}$ & $\begin{array}{l}386.1 \pm 35.2 \\
(1.1)\end{array}$ & $\begin{array}{l}3107.6 \pm 117.9 \\
(8.6)\end{array}$ & $\begin{array}{l}2948.7 \pm 254.0 \\
(8.1)\end{array}$ & $\begin{array}{l}26301.1 \pm 1053.2 \\
(72.4)\end{array}$ \\
\hline & $15-30$ & $\begin{array}{l}0.42 \pm 0.03 \\
(<.01)\end{array}$ & $\begin{array}{l}3294.9 \pm 203.4 \\
(9.6)\end{array}$ & $\begin{array}{l}317.4 \pm 26.2 \\
(0.9)\end{array}$ & $\begin{array}{l}2821.3 \pm 116.6 \\
(8.2)\end{array}$ & $\begin{array}{l}2798.7 \pm 219.7 \\
(8.1)\end{array}$ & $\begin{array}{l}25183.4 \pm 839.2 \\
(73.1)\end{array}$ \\
\hline & $30-45$ & $\begin{array}{l}0.42 \pm 0.05 \\
(<.01)\end{array}$ & $\begin{array}{l}3767.8 \pm 213.7 \\
(11.3)\end{array}$ & $\begin{array}{l}180.4 \pm 31.0 \\
(0.5)\end{array}$ & $\begin{array}{l}2908.0 \pm 122.5 \\
(8.7)\end{array}$ & $\begin{array}{l}2866.3 \pm 208.1 \\
(8.6)\end{array}$ & $\begin{array}{l}23493.8 \pm 1739.3 \\
(70.8)\end{array}$ \\
\hline & $45-60$ & $\begin{array}{l}0.48 \pm 0.09 \\
(<.01)\end{array}$ & $\begin{array}{l}1739.7 \pm 263.2 \\
(7.2)\end{array}$ & $\begin{array}{l}1515.5 \pm 86.0 \\
(6.3)\end{array}$ & $\begin{array}{l}2731.4 \pm 130.0 \\
(11.3)\end{array}$ & $\begin{array}{l}2758.0 \pm 259.4 \\
(11.4)\end{array}$ & $\begin{array}{l}15386.8 \pm 393.9 \\
(63.8)\end{array}$ \\
\hline & Mean & $1.17(<.01)$ & $3092.9(9.6)$ & $599.9(1.9)$ & $2892.1(9.0)$ & $2842.9(8.9)$ & $22341.3(70.5)$ \\
\hline & $\mathrm{CD}_{0.05}$ & 0.19 & 443.5 & 126.4 & NS & NS & 2371.6 \\
\hline
\end{tabular}

*Values in the parenthesis are percentage contribution to total amount

reason for its deposition in the clay enriched horizon (Agbenin, 2003) as envisaged from significant positive correlation between clay content and AFeOX- $\mathrm{Fe}\left(r=0.67^{* *}\right)$. In surface soil, AFeOX$\mathrm{Mn}$ varied from 37.4 to $63.2 \mathrm{ppm}$ (Table 4). AFeOX-Mn was found in a higher amount at $45-60 \mathrm{~cm}$ depth in the plateau top position. Higher amount of Mn below clay enriched horizon is obvious due to its higher mobility as compared to Fe. AFeOX- Zn and AFeOXCu varied from 4.4 to $11.1 \mathrm{ppm}$ and 2.7 to $14.4 \mathrm{ppm}$, respectively in surface soil, which was comparatively higher than the subsurface in the study area (Table 5,6). A considerable amount of these fractions of $\mathrm{Zn}$ and $\mathrm{Cu}$ accumulated in the valley might be due to deposition from elevated landscapes. Further, the higher amount of silt content in the valley and a significant positive correlation between silt content and amorphous oxide occluded $\mathrm{Zn}\left(r=0.78^{* *}\right)$ and $\mathrm{Cu}\left(r=0.72^{* *}\right)$ supported the findings.

Crystalline Fe-oxides occluded (CFeOX) Fe fraction was found in the tune of 2948.7 to $4258.2 \mathrm{ppm}$ in the surface soils of the study area (Table 3). CFeOX- Fe was deposited in the subsurface in the ultisols of plateau top and side slope position. 
Table 4 : Manganese fractions under different landscape positions in Meghalayan plateau, North-Eastern India

\begin{tabular}{|c|c|c|c|c|c|c|c|}
\hline $\begin{array}{l}\text { Landscape } \\
\text { position }\end{array}$ & $\begin{array}{l}\text { Soil depth } \\
\text { (cm) }\end{array}$ & $\begin{array}{l}\text { WS+EX-Mn } \\
\left(\mathrm{mg} \mathrm{kg}^{-1}\right)\end{array}$ & $\begin{array}{l}\text { ORG -Mn } \\
\left(\mathrm{mg} \mathrm{kg}^{-1}\right)\end{array}$ & $\begin{array}{l}\text { MnOX-Mn } \\
\left(\mathrm{mg} \mathrm{kg}^{-1}\right)\end{array}$ & $\begin{array}{l}\text { AFeOX-Mn } \\
\left(\mathrm{mg} \mathrm{kg}^{-1}\right)\end{array}$ & $\begin{array}{l}\text { CFeOX-Mn } \\
\left(\mathrm{mg} \mathrm{kg}^{-1}\right)\end{array}$ & $\begin{array}{l}\text { RES- Mn } \\
\left(\mathrm{mg} \mathrm{kg}^{-1}\right)\end{array}$ \\
\hline \multirow[t]{6}{*}{ Plateau Top } & $0-15$ & $5.3 \pm 0.4(1.8)$ & $33.3 \pm 6.2(11.5)$ & $4.0 \pm 0.2(1.4)$ & $62.9 \pm 3.6(21.7)$ & $55.4 \pm 6.6(19.1)$ & $128.8 \pm 14.9(44.5)$ \\
\hline & $15-30$ & $5.8 \pm 0.5(1.0)$ & $51.1 \pm 6.0(8.6)$ & $21.7 \pm 5.5(3.6)$ & $67.1 \pm 3.0(11.3)^{\prime}$ & $57.9 \pm 9.2(9.7)$ & $391.4 \pm 26.8(65.8)$ \\
\hline & $30-45$ & $7.2 \pm 0.8(1.1)$ & $10.6 \pm 1.9(1.6)$ & $48.0 \pm 5.8(7.1)$ & $67.9 \pm 3.5(10.2)$ & $49.9 \pm 7.0(7.4)$ & $487.3 \pm 15.9(72.6)$ \\
\hline & $45-60$ & $5.1 \pm 0.7(1.0)$ & $7.4 \pm 1.5(1.5)$ & $51.3 \pm 7.1(10.6)$ & $70.5 \pm 4.2(14.5)$ & $34.9 \pm 3.3(7.1)$ & $319.3 \pm 15.0(65.3)$ \\
\hline & Mean & $5.9(1.1)$ & $25.6(5.1)$ & $31.3(6.1)$ & $67.2(13.1)$ & $49.5(9.7)$ & $331.7(64.9)$ \\
\hline & $\mathrm{CD}_{0.05}$ & 1.0 & 11.4 & 10.7 & NS & 8.7 & 32.9 \\
\hline \multirow[t]{6}{*}{ Side slope } & $0-15$ & $3.4 \pm 0.5(2.1)$ & $26.0 \pm 2.8(16.0)$ & $5.3 \pm 1.3(3.3)$ & $53.4 \pm 5.4(32.8)$ & $28.1 \pm 4.3(17.3)$ & $46.5 \pm 9.3(28.6)$ \\
\hline & $15-30$ & $2.3 \pm 0.5(0.8)$ & $27.5 \pm 3.2(9.3)$ & $4.1 \pm 0.2(1.4)$ & $66.9 \pm 2.9(22.6)$ & $31.1 \pm 5.1(10.5)$ & $164.8 \pm 10.2(55.6)$ \\
\hline & $30-45$ & $3.2 \pm 0.6(1.4)$ & $16.9 \pm 2.3(7.4)$ & $8.9 \pm 0.8(3.8)$ & $64.0 \pm 3.3(27.9)$ & $28.9 \pm 5.4(12.6)$ & $107.3 \pm 10.4(46.9)$ \\
\hline & $45-60$ & $3.3 \pm 0.3(1.5)$ & $9.9 \pm 1.6(4.6)$ & $11.4 \pm 1.6(5.3)$ & $64.7 \pm 3.9(30.4)$ & $27.9 \pm 4.3(13.1)$ & $95.3 \pm 15.4(44.9)$ \\
\hline & Mean & $3.0(1.4)$ & $20.1(9.3)$ & $7.4(3.4)$ & $62.3(28.4)$ & $29.0(13.5)$ & $103.5(44.0)$ \\
\hline & $\mathrm{CD}_{0.05}$ & 0.5 & 3.5 & 2.5 & 7.1 & NS & 11.6 \\
\hline \multirow[t]{6}{*}{ Foot slope } & $0-15$ & $3.3 \pm 0.4(2.1)$ & $44.4 \pm 5.0(28.1)$ & $2.9 \pm 0.4(1.8)$ & $37.4 \pm 2.7(23.6)$ & $26.7 \pm 4.1(16.8)$ & $43.7 \pm 4.2(27.6)$ \\
\hline & $15-30$ & $1.8 \pm 0.4(1.1)$ & $27.2 \pm 4.7(16.7)$ & $3.8 \pm 0.4(2.3)$ & $38.9 \pm 3.8(23.9)$ & $29.5 \pm 3.1(18.2)$ & $61.5 \pm 5.4(37.8)$ \\
\hline & $30-45$ & $0.9 \pm 0.1(0.7)$ & $23.6 \pm 2.7(17.2)$ & $4.5 \pm 0.4(3.3)$ & $35.5 \pm 2.5(25.9)$ & $26.8 \pm 3.7(19.5)$ & $46.0 \pm 5.0(33.5)$ \\
\hline & $45-60$ & $0.7 \pm 0.1(0.5)$ & $21.0 \pm 2.5(16.7)$ & $4.2 \pm 0.4(3.4)$ & $30.2 \pm 2.1(24.0)$ & $23.8 \pm 2.2(19.0)$ & $45.7 \pm 3.5(36.4)$ \\
\hline & Mean & $1.7(1.1)$ & $29.1(19.7)$ & $3.9(2.7)$ & $35.5(24.4)$ & $26.7(18.4)$ & $49.2(33.8)$ \\
\hline & $\mathrm{CD}_{0.05}$ & 0.6 & 8.3 & 0.5 & 4.2 & NS & 4.7 \\
\hline \multirow[t]{6}{*}{ Valley } & $0-15$ & $11.6 \pm 0.8(1.6)$ & $97.8 \pm 9.1(13.6)$ & $30.3 \pm 6.5(4.2)$ & $63.2 \pm 5.7(8.8)$ & $36.6 \pm 4.2(5.1)$ & $481.3 \pm 12.7(66.8)$ \\
\hline & $15-30$ & $1.9 \pm 0.4(0.2)$ & $106.0 \pm 9.8(12.9)$ & $86.7 \pm 6.4(10.6)$ & $73.1 \pm 7.4(8.9)$ & $34.1 \pm 4.6(4.1)$ & $519.6 \pm 12.7(63.3)$ \\
\hline & $30-45$ & $5.6 \pm 0.8(0.6)$ & $151.6 \pm 12.3(17.1)$ & $67.0 \pm 5.6(7.6)$ & $81.3 \pm 6.9(9.2)$ & $42.9 \pm 5.2(4.8)$ & $536.5 \pm 9.5(60.6)$ \\
\hline & $45-60$ & $2.0 \pm 0.5(0.4)$ & $80.4 \pm 8.8(15.6)$ & $87.4 \pm 6.4(16.9)$ & $63.6 \pm 6.7(12.3)$ & $30.7 \pm 5.2(6.0)$ & $252.3 \pm 6.4(48.9)$ \\
\hline & Mean & $5.3(0.7)$ & $108.9(14.8)$ & $67.8(9.8)$ & $70.3(9.8)$ & $36.1(5.0)$ & $447.4(59.9)$ \\
\hline & $\mathrm{CD}_{0.05}$ & 0.9 & 10.3 & 14.7 & 13.4 & 3.9 & 19.6 \\
\hline
\end{tabular}

*Values in the parenthesis are percentage contribution to total amount

Table 5: Zinc fractions under different landscape positions in Meghalayan plateau, North-Eastern India

\begin{tabular}{|c|c|c|c|c|c|c|c|}
\hline $\begin{array}{l}\text { Landscape } \\
\text { position }\end{array}$ & $\begin{array}{l}\text { Soil depth } \\
\text { (cm) }\end{array}$ & $\begin{array}{l}\text { WS+EX-Zn } \\
\left(\mathrm{mg} \mathrm{kg}^{-1}\right)\end{array}$ & $\begin{array}{l}\text { ORG-Zn } \\
\left(\mathrm{mg} \mathrm{kg}^{-1}\right)\end{array}$ & $\begin{array}{l}\mathrm{MnOX}-\mathrm{Zn} \\
\left(\mathrm{mg} \mathrm{kg}^{-1}\right)\end{array}$ & $\begin{array}{l}\text { AFeOX-Zn } \\
\left(\mathrm{mg} \mathrm{kg}^{-1}\right)\end{array}$ & $\begin{array}{l}\text { CFeOX-Zn } \\
\left(\mathrm{mg} \mathrm{kg}^{-1}\right)\end{array}$ & $\begin{array}{l}\text { RES- } \mathrm{Zn} \\
\left(\mathrm{mg} \mathrm{kg}^{-1}\right)\end{array}$ \\
\hline \multirow[t]{6}{*}{ Plateau Top } & $0-15$ & $0.89 \pm 0.11(2.3)$ & $3.3 \pm 0.2(8.4)$ & $0.15 \pm 0.02(0.4)$ & $4.4 \pm 0.2(11.3)$ & $5.3 \pm 1.0(13.6)$ & $24.9 \pm 3.7(64.0)$ \\
\hline & $15-30$ & $0.07 \pm 0.02(0.1)$ & $1.9 \pm 0.3(2.3)$ & $0.15 \pm 0.02(0.2)$ & $3.1 \pm 0.2(3.7)$ & $4.50 \pm 0.2(5.5)$ & $72.5 \pm 4.7(88.2)$ \\
\hline & $30-45$ & $0.07 \pm 0.01(0.1)$ & $1.0 \pm 0.1(1.8)$ & $0.10 \pm 0.01(0.2)$ & $2.4 \pm 0.2(4.1)$ & $3.4 \pm 0.5(5.8)$ & $51.4 \pm 4.0(88.0)$ \\
\hline & $45-60$ & $0.04 \pm 0.02(0.1)$ & $1.3 \pm 0.1(1.9)$ & $0.19 \pm 0.03(0.3)$ & $2.2 \pm 0.1(3.3)$ & $1.6 \pm 0.2(2.4)$ & $61.9 \pm 3.8(92.1)$ \\
\hline & Mean & $0.27(0.6)$ & $1.9(3.6)$ & $0.15(0.3)$ & $3.0(5.6)$ & $3.7(6.8)$ & $52.7(83.1)$ \\
\hline & $C D_{0.05}$ & 0.18 & 0.5 & 0.04 & 0.4 & 1.7 & 4.0 \\
\hline \multirow[t]{6}{*}{ Side slope } & $0-15$ & $0.38 \pm 0.08(0.9)$ & $2.6 \pm 0.2(6.1)$ & $0.09 \pm 0.02(0.2)$ & $5.2 \pm 0.3(12.3)$ & $3.2 \pm 0.3(7.4)$ & $30.9 \pm 4.1(73.1)$ \\
\hline & $15-30$ & $0.06 \pm 0.02(0.1)$ & $1.6 \pm 0.2(2.1)$ & $0.06 \pm 0.01(0.1)$ & $3.6 \pm 0.2(4.6)$ & $2.9 \pm 0.4(3.7)$ & $69.4 \pm 3.6(89.4)$ \\
\hline & $30-45$ & $0.05 \pm 0.01(0.1)$ & $1.5 \pm 0.2(2.6)$ & $0.07 \pm 0.01(0.1)$ & $3.1 \pm 0.2(5.4)$ & $3.5 \pm 0.3(6.0)$ & $49.5 \pm 3.8(85.7)$ \\
\hline & $45-60$ & $0.05 \pm 0.01(0.1)$ & $1.4 \pm 0.3(2.8)$ & $0.06 \pm 0.01(0.1)$ & $3.1 \pm 0.3(6.3)$ & $3.4 \pm 0.4(7.0)$ & $40.8 \pm 3.9(83.6)$ \\
\hline & Mean & $0.13(0.2)$ & $1.9(3.3)$ & $0.07(0.1)$ & $3.7(6.6)$ & $3.2(5.7)$ & $47.6(84.1)$ \\
\hline & $C D_{0.05}$ & 0.12 & 0.6 & 0.01 & 0.4 & 0.4 & 3.2 \\
\hline \multirow[t]{6}{*}{ Foot slope } & $0-15$ & $0.16 \pm 0.04(0.3)$ & $5.2 \pm 0.2(10.2)$ & $0.13 \pm 0.02(0.3)$ & $8.0 \pm 0.5(15.6)$ & $4.9 \pm 0.4(9.6)$ & $32.6 \pm 3.2(64.0)$ \\
\hline & $15-30$ & $0.07 \pm 0.02(0.2)$ & $3.2 \pm 0.2(8.1)$ & $0.12 \pm 0.02(0.3)$ & $5.7 \pm 0.2(14.2)$ & $5.0 \pm 0.4(12.5)$ & $25.9 \pm 2.4(64.7)$ \\
\hline & $30-45$ & $0.08 \pm 0.02(0.3)$ & $2.3 \pm 0.1(7.5)$ & $0.11 \pm 0.03(0.4)$ & $5.10 \pm 0.2(16.5)$ & $4.2 \pm 0.2(13.5)$ & $19.3 \pm 0.5(62.0)$ \\
\hline & $45-60$ & $0.06 \pm 0.02(0.2)$ & $1.1 \pm 0.2(3.0)$ & $0.10 \pm 0.02(0.3)$ & $4.2 \pm 0.2(11.5)$ & $4.3 \pm 0.2(11.5)$ & $27.1 \pm 3.2(73.6)$ \\
\hline & Mean & $0.09(0.2)$ & $3.0(7.2)$ & $0.12(0.3)$ & $5.7(14.4)$ & $4.6(11.8)$ & $26.2(66.0)$ \\
\hline & $C D_{0.05}$ & 0.04 & 0.2 & 0.02 & 0.6 & 0.5 & 4.8 \\
\hline \multirow[t]{6}{*}{ Valley } & $0-15$ & $0.16 \pm 0.04(0.1)$ & $4.2 \pm 0.5(2.7)$ & $0.42 \pm 0.03(0.3)$ & $11.1 \pm 0.3(7.1)$ & $10.3 \pm 0.4(6.7)$ & $128.8 \pm 4.2(83.1)$ \\
\hline & $15-30$ & $0.04 \pm 0.01(0.0)$ & $2.9 \pm 0.3(2.8)$ & $0.45 \pm 0.03(0.5)$ & $8.9 \pm 0.3(8.6)$ & $7.4 \pm 0.3(7.2)$ & $83.7 \pm 3.2(81.0)$ \\
\hline & $30-45$ & $0.96 \pm 0.09(1.0)$ & $4.9 \pm 0.4(5.0)$ & $0.22 \pm 0.02(0.2)$ & $9.5 \pm 0.5(9.7)$ & $8.6 \pm 0.6(8.7)$ & $73.8 \pm 3.9(75.4)$ \\
\hline & $45-60$ & $0.09 \pm 0.02(0.1)$ & $2.6 \pm 0.4(4.3)$ & $0.85 \pm 0.03(1.4)$ & $8.7 \pm 0.3(14.4)$ & $6.6 \pm 0.3(10.9)$ & $41.5 \pm 3.9(68.8)$ \\
\hline & Mean & $0.31(0.3)$ & $3.6(3.5)$ & $0.50(0.5)$ & $9.5(9.1)$ & $8.2(7.9)$ & $81.9(78.7)$ \\
\hline & $\mathrm{CD}_{0.05}$ & 0.14 & 0.6 & 0.05 & 0.5 & 0.6 & 14.3 \\
\hline
\end{tabular}

*Values in the parenthesis are percentage contribution to total amount 
Table 6 : Copper fractions under different landscape positions in Meghalayan plateau, North-Eastern India

\begin{tabular}{|c|c|c|c|c|c|c|c|}
\hline $\begin{array}{l}\text { Landscape } \\
\text { position }\end{array}$ & $\begin{array}{l}\text { Soil depth } \\
\text { (cm) }\end{array}$ & $\begin{array}{l}\text { WS+EX-Cu } \\
\left(\mathrm{mg} \mathrm{kg}^{-1}\right)\end{array}$ & $\begin{array}{l}\text { ORG-Cu } \\
\left(\mathrm{mg} \mathrm{kg}^{-1}\right)\end{array}$ & $\begin{array}{l}\text { MnOX-Cu } \\
\left(\mathrm{mg} \mathrm{kg}^{-1}\right)\end{array}$ & $\begin{array}{l}\text { AFeOX-Cu } \\
\left(\mathrm{mg} \mathrm{kg}^{-1}\right)\end{array}$ & $\begin{array}{l}\text { CFeOX-Cu } \\
\left(\mathrm{mg} \mathrm{kg}^{-1}\right)\end{array}$ & $\begin{array}{l}\text { RES-Cu } \\
\left(\mathrm{mg} \mathrm{kg}^{-1}\right)\end{array}$ \\
\hline \multirow[t]{6}{*}{ Plateau Top } & $0-15$ & $1.02 \pm 0.09(3.7)$ & $3.9 \pm 0.2(13.9)$ & $0.36 \pm 0.04(1.3)$ & $4.7 \pm 0.3(16.9)$ & $6.4 \pm 0.3(23.1)$ & $11.4 \pm 1.2(41.1)$ \\
\hline & $15-30$ & $0.32 \pm 0.05(1.0)$ & $2.2 \pm 0.1(7.0)$ & $0.32 \pm 0.05(1.0)$ & $3.2 \pm 0.2(10.4)$ & $5.2 \pm 0.2(16.9)$ & $19.4 \pm 1.2(63.6)$ \\
\hline & $30-45$ & $0.27 \pm 0.04(0.8)$ & $2.0 \pm 0.2(6.2)$ & $0.36 \pm 0.05(1.1)$ & $2.4 \pm 0.3(7.5)$ & $4.5 \pm 0.2(14.1)$ & $22.6 \pm 1.1(70.2)$ \\
\hline & $45-60$ & $0.45 \pm 0.04(1.2)$ & $1.20 \pm 0.1(3.2)$ & $0.04 \pm 0.01(0.1)$ & $1.7 \pm 0.3(4.5)$ & $3.6 \pm 0.2(9.6)$ & $30.4 \pm 1.4(81.3)$ \\
\hline & Mean & $0.51(1.6)$ & $2.3(7.2)$ & $0.27(0.8)$ & $3.0(9.4)$ & $4.9(15.4)$ & $20.965 .6)$ \\
\hline & $C D_{0.05}$ & 0.11 & 0.3 & 0.09 & 0.4 & 0.5 & 1.5 \\
\hline \multirow[t]{6}{*}{ Side slope } & $0-15$ & $0.46 \pm 0.04$ & $2.5 \pm 0.1(14.9)$ & $0.06 \pm 0.01(0.4)$ & $2.7 \pm 0.1(16.5)$ & $2.3 \pm 0.2(13.7)$ & $8.6 \pm 0.9(51.8)$ \\
\hline & $15-30$ & $0.48 \pm 0.05(2.8)$ & $2.4 \pm 0.1(13.6)$ & $0.06 \pm 0.01(0.3)$ & $3.0 \pm 0.1(17.3)$ & $2.5 \pm 0.2(14.5)$ & $9.0 \pm 0.8(51.4)$ \\
\hline & $30-45$ & $0.50 \pm 0.04(3.6)$ & $2.3 \pm 0.1(16.2)$ & $0.04 \pm 0.01(0.3)$ & $2.8 \pm 0.1(20.1)$ & $2.7 \pm 0.2(19.0)$ & $5.6 \pm 0.7(40.8)$ \\
\hline & $45-60$ & $0.58 \pm 0.03(4.7)$ & $2.2 \pm 0.1(17.9)$ & $0.08 \pm 0.02(0.6)$ & $2.8 \pm 0.1(22.1)$ & $2.6 \pm 0.2(20.8)$ & $4.2 \pm 0.6(34.0)$ \\
\hline & Mean & $0.51(3.4)$ & $2.3(15.7)$ & $0.06(0.4)$ & $2.8(19.0)$ & $2.5(17.0)$ & $6.9(44.5)$ \\
\hline & $\mathrm{CD}_{0.05}$ & 0.06 & 0.2 & NS & 0.2 & 0.2 & 1.3 \\
\hline \multirow[t]{6}{*}{ Foot slope } & $0-15$ & $0.55 \pm 0.02(3.6)$ & $4.5 \pm 0.3(29.3)$ & $0.06 \pm 0.01(0.4)$ & $3.9 \pm 0.4(25.3)$ & $2.3 \pm 0.2(15.1)$ & $4.1 \pm 0.5(26.4)$ \\
\hline & $15-30$ & $0.54 \pm 0.03(4.0)$ & $4.1 \pm 0.3(30.1)$ & $0.02 \pm 0.00(0.1)$ & $3.0 \pm 0.3(22.4)$ & $2.0 \pm 0.1(14.8)$ & $3.9 \pm 0.6(28.6)$ \\
\hline & $30-45$ & $0.60 \pm 0.05(4.1)$ & $3.9 \pm 0.4(26.7)$ & $0.01 \pm 0.00(0.1)$ & $3.4 \pm 0.3(23.3)$ & $2.1 \pm 0.2(14.0)$ & $4.7 \pm 0.5(31.8)$ \\
\hline & $45-60$ & $0.56 \pm 0.04(4.0)$ & $3.6 \pm 0.3(26.0)$ & $0.04 \pm 0.01(0.3)$ & $3.1 \pm 0.4(22.0)$ & $2.0 \pm 0.1(14.1)$ & $4.7 \pm 0.4(33.6)$ \\
\hline & Mean & $0.56(3.9)$ & $4.0(28.0)$ & $0.03(0.2)$ & $3.4(23.2)$ & $2.1(14.5)$ & $4.3(30.1)$ \\
\hline & $\mathrm{CD}_{0.05}$ & NS & 0.5 & 0.02 & 0.5 & NS & 0.4 \\
\hline \multirow[t]{6}{*}{ Valley } & $0-15$ & $0.76 \pm 0.03(1.1)$ & $11.5 \pm 0.3(16.0)$ & $0.02 \pm 0.01(0.0)$ & $14.4 \pm 0.8(20.1)$ & $9.3 \pm 0.3(13.0)$ & $35.7 \pm 1.6(49.8)$ \\
\hline & $15-30$ & $0.63 \pm 0.03(1.3)$ & $7.7 \pm 0.3(15.9)$ & $0.04 \pm 0.02(0.1)$ & $10.3 \pm 0.3(21.3)$ & $12.3 \pm 0.2(25.4)$ & $17.5 \pm 1.7(36.1)$ \\
\hline & $30-45$ & $0.68 \pm 0.03(1.3)$ & $10.8 \pm 0.2(20.7)$ & $0.02 \pm 0.01(0.0)$ & $12.7 \pm 0.7(24.3)$ & $13.6 \pm 0.3(26.0)$ & $14.5 \pm 0.7(27.7)$ \\
\hline & $45-60$ & $0.62 \pm 0.02(2.0)$ & $4.6 \pm 0.3(14.9)$ & $0.07 \pm 0.02(0.2)$ & $8.8 \pm 0.5(28.6)$ & $9.5 \pm 0.2(30.9)$ & $7.2 \pm 0.4(23.5)$ \\
\hline & Mean & $0.67(1.3)$ & $8.7(17.1)$ & $0.04(0.1)$ & $11.6(22.7)$ & $11.2(22.0)$ & $18.7(36.7)$ \\
\hline & $\mathrm{CD}_{0.05}$ & 0.04 & 0.4 & 0.03 & 1.6 & 0.4 & 2.6 \\
\hline
\end{tabular}

*Values in the parenthesis are percentage contribution to total amount

However, a higher amount of $\mathrm{CFeOX}$ - Fe found in the surface layer of the valley, classified as inceptisols. Comparing the different landscape position, it decreased with elevation and found in the order plateau top $>$ foot slope = side slope $>$ valley, similar to the findings of Wei et al. (2010). Similar to Fe, this fraction of $\mathrm{Mn}$ was found to decrease with elevation from plateau top to foot slope, except in valley (Table 4). CFeOX- Zn was measured in the range of 2.4 to $13.6 \%$ of total $\mathrm{Zn}$ (Table 5) whereas, 9.6 to $30.9 \%$ of total Cu was occluded to this fraction (Table 6).

Residual (RES) Fe was 53.8 to $79.9 \%$ of total Fe (Table 3 ) whereas, 27.6 to $72.6 \%$ of total $\mathrm{Mn}$ (Table 4 ) was bound to this fraction over $60 \mathrm{~cm}$ soil depth. In the case of $\mathrm{Zn}$ and $\mathrm{Cu}, 62.0$ to $92.1 \%$ (Table 5) and 23.5 to $81.3 \%$ (Table 6), respectively were measured in the residual fraction.

DTPA extractable Fe was positively correlated $\left(r=0.48^{* *}\right)$ with WS+EX-Fe fraction although it was measured $1.8 \%$ of DTPA extractable Fe on an average (Young et al., 2006). Hence, rests of the amounts were contributed by other Fe fractions. DTPA-Mn showed significant correlation with WS+EX $\left(r=0.98^{* *}\right)$, CFeOX $\left(r=0.50^{* *}\right)$, AFeOX $\left(r=0.42^{* *}\right)$ and ORG fraction $\left(r=0.33^{*}\right)$, made difficult to find out the relative important fractions which contributed most to the DTPA extractable pool after water soluble and exchangeable fraction $\left(r=0.98^{\star *}\right)$. Similarly, WS+EX fraction was positively correlated with DTPA-Zn $\left(r=0.47^{\star *}\right)$ and DTPA-Cu $\left(r=0.48^{* *}\right)$. DTPA extractable $\mathrm{Cu}$ was also correlated with ORG $\left(r=0.96^{* *}\right)$, AFeOX $\left(r=0.96^{* *}\right)$ and CFeOX occluded $\left(r=0.78^{* *}\right)$ and WS+EX fraction $\left(r=0.48^{*}\right)$ and thus these fractions also contributed to the Cu availability.

As correlation alone cannot be used to predict the relations among several fractions and their contribution towards availability hence, a factor analysis was performed with all the micronutrient fractions and plotted in a graph. The figure revealed that (Fig. 2) after WS+EX, ORG-Fe was the largest fraction to contribute DTPA extractable pool similar to the findings of Young et al. (2006). However, CFeOX-Mn fraction might be considered as an important fraction that can act as a reserve pool and contributed to the labile pools in acid soil of Meghalaya. Similar findings in acidic soil have also been reported by Joshi et al. (2017). The factor plot of $\mathrm{Zn}$ revealed that ORG, AFeOX and CFeOX-Zn lied in close proximity with each other and contributed to the available pool, whereas the DTPA extracted Cu from ORG, $\mathrm{AFeOX}$ and $\mathrm{CFeOX}$ fractions and it was supported by Agbenin and Olozo (2004). 

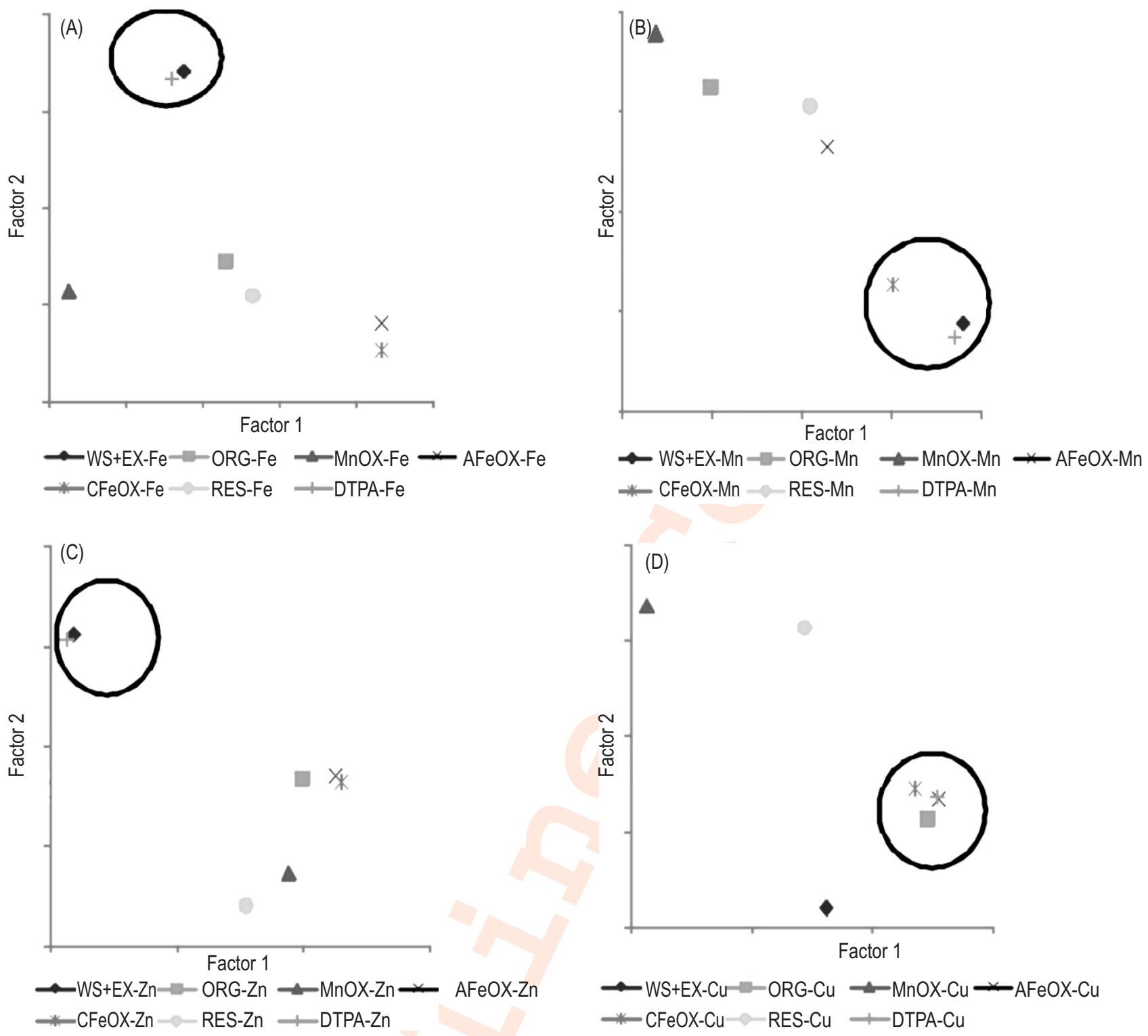

Fig. 2 : Factor plot showing the loading of (A) Fe; (B) Mn; (C) Zn and (D) Cu fractions on two factors derived from correlation matrix after VARIMAX rotation.

Soil organic matter complexed fractions of most of the micronutrients remain in available form. Hence, maintaining soil organic carbon status is of utmost importance. Besides, $\mathrm{Zn}$ deficiency was found in majority of the soils whereas, DTPA extractable Mn was also found below its critical limit in few subsurface soils. Hence, a special emphasis on monitoring micronutrients especially $\mathrm{Zn}$ status of soil and its inclusion in fertilization is necessary in this part of sub tropical north eastern region of India.

\section{Acknowledgment}

The authors thank the Meghalaya Basin Development Authority (MBDA), Govt. of Meghalaya, India for funding the project (PIMS-ICAR reference no. OXXO2855).

\section{References}

Adhikari, D. and Y. Yang: Selective stabilization of aliphatic organic carbon by iron oxide. Sci. Rep., 5, 1-7 (2015)

Adriano, D.C.: Trace elements in terrestrial environments. SpringerVerlag, New York, pp. 29-59 (2001).

Agbenin, J.O. and L.A. Olozo: Competitive adsorption of copper and zinc by a Bt horizon of a savanna Alfisol as affected by $\mathrm{pH}$ and selective removal of hydrous oxides and organic matter. Geoderma, 119, 85-95 (2004).

Agbenin, J.O.: The distribution and transformation of iron and manganese in soil fractions in a savanna Alfisol under continuous cultivation. Nutr. Cycl. Agroecosys., 66, 259-270 (2003).

Alloway, B.J.: Micronutrients and Crop Production: An Introduction. In: Micronutrient Deficiencies in Global Crop Production.(Ed.: B.J. Alloway). Springer, New York, pp. 1-39 (2008). 
Bandyopadhyay, S., P. Ray, S. Padua, S. Ramachandran, R.K. Jena, P.D. Roy, D.P. Dutta, S.K. Singh and S.K. Ray: Priority zoning of available micronutrients in the soils of agroecological sub-regions of north-east India using geo-spatial techniques. Agric. Res., 7, 200-214 (2018).

Bhattacharya, T., T.K. Sen, R.S. Singh, D.C. Nayak and J.L. Sehgal: Morphological characteristics and classification of ultisols with kandic horizon in north eastern region. J. Indian Soc. Soil Sci., 42, 301-306 (1994).

Choudhury, B.U., K.P. Mohapatra, A. Das, P.T. Das, L. Nongkhlaw, R.A. Fiyaz, S.V. Ngachan, S. Hazarika, D.J. Rajkhowa and G.C. Munda: Spatial variability in distribution of organic carbon stocks in the soils of north east India. Curr. Sci., 104, 604-614 (2013).

Debroy, P., R. P. Narwal, R.S. Malik, B.N. Saha and S. Kumar: Impact of zinc application methods on green gram (Vigna radiata L.) productivity and grain zinc fortification. J. Environ. Biol., 35, 851855 (2014).

Fisher, R.F. and D. Binkley: Ecology and management of forest soils. John Wiley and Sons, New York, pp. 13-43 (2000).

Graham, R.D.: Micronutrient deficiencies in crops and their global significance. In: Micronutrient deficiencies in global crop production (Ed.: B.J. Alloway). Springer, Dordrecht, pp. 41-61 (2008)

Hesse, P.R.: A Text Book of Soil Chemical Analysis. CBS Publishers and Distributors, Delhi, pp. 91-105 (1971).

Jackson, M.L.: Soil Chemical Analysis. Prentice Hall. Inc., New Jersey, pp. 46-47 (1958).

Joshi, D., P.C. Srivastava, R. Dwivedi, S.P. Pachauri and A.K. Shukla: Chemical fractions of $\mathrm{Mn}$ in acidic soils and selection of suitable soil extractants for assessing Mn availability to maize (Zea Mays L.), Commun. Soil Sci. Plan., 48, 886-897 (2017).

Kumar, A., A. Sen and R. Kumar: Micronutrient fortification in crop to enhance growth, yield and quality of aromatic rice. J. Environ. Biol. 37, 973-977 (2016).

Lee, B.D., B.J. Carter, N.T. Basta and B. Weaver: Factors influencing heavy metal distribution in six oklahoma benchmark soils. Soil Sci. Soc. Am. J., 61, 218-223 (1997).

Lim, C.H. and M.L. Jackson: Dissolution of total elemental analysis. In: Methods of Soil Analysis: Chemical and Microbiological Properties (Eds.: A.L. Page, R.H. Miller and D.R. Keeney). Part 1, American Society of Agronomy, Madison, Wisconsin, pp. 1-12 (1982).

Lindsay, W.L. and W.A. Norvell: Development of DTPA soil test for zinc, iron, manganese and copper. Soil Sci. Soc. Am. J., 42, 421-428 (1978).

Mandal, L.N. and B. Mandal: Zinc fractions in soils in relation to zinc nutrition of lowland rice. Soil Sci., 142, 141-148 (1986).

McDaniel, P.A., G.R. Bathke, S.W. Buol, D.K. Cassel and A.C. Fallen: Secondary manganese/ iron ratios as pedochemical indicators of field-scale through-flow water movement. Soil Sci. Soc. Am. J., 56, 1211-1217(1992).

Mortvedt, J.J.: Bioavailability of micronutrients. In: Handbook of Soil Science (Ed.: M.E. Sumner). CRC Press, Boca Raton, Fl., pp. 71$78(2000)$.

Nascimentoa, C.W.A., A.B. Oliveiraa, M.R. Ribeiroa and E.E.C. Meloa:
Distribution and availability of zinc and copper in benchmark soils of Pernambuco state, Brazil. Commun. Soil Sci. Plant Anal., 37, 109-125 (2006).

Nayak, D.C., T.K. Sen, G.S. Chamuah and J.S. Sehgal: Nature of soil acidity in some soils of Manipur. J. Indian Soc. Soil Sci., 44, 209-14 (1996).

Nayyar, V.K., U.S. Sadana and P.N. Takkar: Methods and rates of application of $\mathrm{Mn}$ and its critical level for wheat following rice on coarse textured soils. Fert. News, 8, 173-178 (1985).

Piper, C.S.: Soil and plant analysis: A laboratory manual of methods for the examination of soils and the determination of the inorganic constituents of plants. Hans Publications, Bombay, pp.135-136 (1966).

Post, J.E.: Manganese oxide minerals: crystal structures and economic and environmental significance. Proc. Natl. Acad. Sci. U.S.A., 96, 3447-3454 (1999).

Rengel, Z: Availability of $\mathrm{Mn}, \mathrm{Zn}$ and $\mathrm{Fe}$ in the rhizosphere. J. Soil Sci. Plant Nut., 15, 397-409 (2015).

Sharma, B.D., S.S. Mukhopadhyay and H. Arora: Total and DTPAextractable micronutrients in relation to pedogenesis in some alfisols of Punjab, India. Soil Sci., 170, 559-572 (2005).

Shukla, A.K., P.K. Tiwari and C. Prakash: Micronutrients deficiencies visà-vis food and nutritional security of India. Indian J. Fert., 10, 94112 (2014).

Shukla, A.K., S.K. Behera, A. Pakhre and S.K. Chaudhari: Micronutrients in soils, plants, animals and humans. Indian J. Fert., 14, 30-54, (2018).

Singh, A.K. and S.V. Ngachan: Climate change and food security in North-Eastern region of India.In: Carbon Management in Agriculture for Mitigating Greenhouse Effect. (Eds.: A.K. Singh, S.V. Ngachan, G.C. Munda, K.P. Mohapatra, B.U. Choudhury, A. Das, S.C. Rao, D.P. Patel, D.J. Rajkhowa, G.I. Ramkrushna and A.S. Panwar). ICAR Research Complex for NEH region, Umiam, Meghalaya, India, pp 1-16 (2012).

Takkar, P.N. and M.S. Mann: Evaluation of analytical methods for estimating available zinc responses of maize to applied zinc in major soil series of Ludhiana, Punjab (India). Agrochimica, 19, 420-430 (1975).

Takkar, P.N. and A.K. Shukla: Soil Health. In: State of Indian Agriculture. (Eds.: H. Pathak, S.K. Sanyal and P.N. Takkar). NAAS, New Delhi, India, pp.121-152 (2015)

Walkley, A.J. and I.A. Black: An examination of the destructive method for determining soil organic matter and a proposed modification of the chromic acid titration method. Soil Sci., 37, 29-38 (1934).

Wei, X., M. Hao, M. Shao and W.J. Gale: Changes in soil properties and the availability of soil micronutrients after 18 years of cropping and fertilization. Soil Till. Res., 91, 120-130 (2006)

Wei, X., M. Shao, J. Zhuang and R. Horton: Soil iron fractionation and availability at selected landscape positions in a loessial gully region of northwestern China. Soil Sci. Plant Nutr., 56, 617-626 (2010).

Young, K.C., P.A. Maurice and L.E. Hersman: Acquisition of Fe from various natural organic matter isolates by aerobic pseudomonad bacteria. Geomicrobiol. J., 23, 183-188 (2006). 